\title{
Acquisition of anticancer drug resistance is partially associated with cancer stemness in human colon cancer cells
}

\author{
FLARIA EL KHOURY, LAURENT CORCOS, STÉPHANIE DURAND, \\ BRIGITTE SIMON and CATHERINE LE JOSSIC-CORCOS
}

INSERM-UBO UMR1078-ECLA, IBSAM, Faculty of Medicine, University of Brest, 29200 Brest, France

Received May 17, 2016; Accepted July 15, 2016

DOI: $10.3892 /$ ijo.2016.3725

\begin{abstract}
Colorectal cancer (CRC) is one of the most aggressive cancers worldwide. Several anticancer agents are available to treat CRC, but eventually cancer relapse occurs. One major cause of chemotherapy failure is the emergence of drug-resistant tumor cells, suspected to originate from the stem cell compartment. The aim of this study was to ask whether drug resistance was associated with the acquisition of stem cell-like properties. We isolated drug-resistant derivatives of two human CRC cell lines, HT29 and HCT116, using two anticancer drugs with distinct modes of action, oxaliplatin and docetaxel. HT29 cells resistant to oxaliplatin and both HT29 and HCT116 cells resistant to docetaxel were characterized for their expression of genes potentially involved in drug resistance, cell growth and cell division, and by surveying stem cell-like phenotypic traits, including marker genes, the ability to repair cell-wound and to form colonospheres. Among the genes involved in platinum or taxane resistance (MDR1, $A B C G 2, M R P 2$ or $A T P 7 B), M D R 1$ was uniquely overexpressed in all the resistant cells. An increase in the cyclin-dependent kinase inhibitor p21, in cyclin D1 and in CD26, CD166 cancer stem cell markers, was noted in the resistant cells, together with a higher ability to form larger and more abundant colonospheres. However, many phenotypic traits were selectively altered in either HT29- or in HCT116-resistant cells. Expression of EPHB2, ITG $\beta-1$ or Myc was specifically increased in the HT29-resistant cells, whereas only HCT116-resistant cells efficiently repaired cellwounds. Taken together, our results show that human CRC cells selected for their resistance to anticancer drugs displayed a few stem cell characteristics, a small fraction of which was shared between cell lines. The occurrence of marked phenotypic differences between HT29- and HCT116-drug resistant cells indicates that the acquired resistance depends mostly on
\end{abstract}

Correspondence to: Dr Catherine Le Jossic-Corcos, INSERM-UBO UMR1078-ECLA, IBSAM, Faculty of Medicine, University of Brest, 22 Avenue Camille Desmoulins, 29200 Brest, France

E-mail: catherine.corcos@univ-brest.fr

Key words: colon cancer, chemotherapy, oxaliplatin, docetaxel, cancer stem cells the parental cell characteristics, rather than on the drug type used.

\section{Introduction}

Colorectal cancer is the third most common cancer worldwide (1), with nearly 1.36 million new cases diagnosed in 2012 (2). A major impediment in the success of available therapies is the recurrent adaptation of cancer cells, which evade from the tumor, and eventually reach and settle at distant sites, leading to metastases, which are often considered as the point of no return, and are associated with the worst outcome. Therefore, understanding the mechanisms that drive resistance of cancer cells bears special importance. Several such mechanisms have been studied in depth in numerous experimental setups. These include, but are not limited to: i) increased clearance of the drugs, either through increased efflux, decreased influx or increased metabolism that limit the in-cell life span of the compounds; ii) decreased metabolic conversion/activation of pro-drugs, which restricts the cytotoxic effect of the active product; iii) increased repair capacity towards cytotoxic or genotoxic damage; iv) decreased engagement of the apoptotic machinery in response to drugs (3). A rational way to understand resistance is to isolate, from cancer cells grown in vitro, cells that are resistant to therapy, and to analyze their phenotypic properties. In the context of colon cancer, as for other epithelial cancers, it has been proposed that cancer cells may originate from a small fraction of tumor initiating cells, or cancer stem cells (CSC) that are located near the bottom of the crypts $(4,5)$. There is a set of therapeutic strategies based on usage of anticancer agents such as oxaliplatin or irinotecan, among many others, in colon cancer. Oxaliplatin, a third generation platinum derivative, is frequently used for treating advanced CRC, in association with 5-fluorouracil. This platinum analogue inhibits tumor cell growth by covalent DNA binding (6). Several studies reported that platinum agents enter the cells by passive diffusion and may be detoxified predominantly by the glutathione system (3). Docetaxel (taxotere), an analogue of taxol, inhibits cell replication upon promoting the in vitro assembly of stable microtubules and inducing microtubule-bundle formation (7). It is used for the treatment of a number of solid tumors such as breast, prostate, non-small cell lung cancer, and gastric adenocarcinoma, but it had limited activity in colon cancer patients (8). Passive diffu- 
sion is believed to be the mechanism of uptake for docetaxel due to its lipophilic characteristics, although the organic anion transporting polypeptides (OATPs) could also play a role in its uptake (9). Docetaxel is mainly metabolized in the liver by cytochrome P450 3A4 (CYP3A4), and to a minor extent by CYP3A5 (10), and then eliminated by the multidrug resistance protein 1 (MDR1, ABCB1, P-glycoprotein) among others (11). However, intrinsic or acquired resistance to these drugs is one of the major obstacles in the use of these agents in therapy $(11,12)$. Platinum resistance is a process that could mainly include deregulation in drug transport and detoxification, DNA repair and impairment of apoptosis (3). Likely, taxane resistance is associated with modifications in drug efflux mechanisms, involving the adenosine triphosphate (ATP)-binding cassette (ABC) transporter family (13). The link between CSC and drug resistance has been reported in several studies $(13,14)$. The existence of CSC within solid tumors, such as breast (15), pancreas $(16)$, brain $(17)$ and colon $(18,19)$ or even in hematopoietic cancers (20) is rather accepted. CSC are particularly resistant to drugs, in part as a result of high expression levels of ATP-binding cassette (ABC) transporters, a high DNA repair capacity and increased levels of anti-apoptotic factors (21-23). In addition, signaling pathways involved in differentiation and migration, such as the Wnt, Notch, Hedgehog or BMP/TGF $\beta$ pathways, may be altered as a result of cancer promoting mutations $(5,24,25)$. These pathways have been found to play a role in the regulation of the self-renewal of CSC but also in the regulation of the chemoresistant cells (26). In this study, we generated cells resistant to oxaliplatin or docetaxel, two cytotoxic drugs with distinct modes of action. We characterized a number of phenotypic features, both directly associated to chemo-resistance and related to CSC characteristics. Our results confirm and extend previous studies, and further show that acquired drug resistance depends more on the type of cancer cell than on the drug type.

\section{Materials and methods}

Cell lines and culture conditions. HT29 cells were cultured in Dulbecco's modified Eagle's medium (DMEM; $4.5 \mathrm{~g} / 1$ glucose) (Lonza, Belgium) supplemented with $10 \%$ fetal bovine serum (FBS) (Gibco Invitrogen, USA), and HCT116 cells were maintained in Dulbecco's modified Eagle's medium: nutrient mixture F-12 (DMEM/F-12) (Lonza, Belgium), supplemented with $5 \%$ FBS. All cultures were incubated at $37^{\circ} \mathrm{C}$ in a humidified atmosphere containing $5 \% \mathrm{CO}_{2}$. The medium was changed every two days, and cells were passaged using $0.05 \%$ trypsin/EDTA (Gibco Invitrogen).

Cell viability and growth. Cell viability of HT29 and HCT116 cells was measured by the colorimetric MTT (3-(4,5-dimethylthiazol-2-yl)-2,5-diphenyltetrazolium bromide) test (EMD Millipore, USA). HT29 or HCT116 cells $(7,500)$ were seeded in $100 \mu \mathrm{l}$ medium into each well of 96 -well plates and incubated for $24 \mathrm{~h}$ at $37^{\circ} \mathrm{C}$. The medium was then changed with fresh medium and exposed for 24,48 or $72 \mathrm{~h}$ to the drugs at the following concentrations: $5 \mathrm{nM}$ docetaxel (Accord Healthcare, France), $10 \mu \mathrm{M}$ oxaliplatin (Teva Santé, France), $50 \mu \mathrm{M}$ 5-fluorouracil (Pfizer, USA) or $1 \mu \mathrm{M}$ camptothecin (Sigma, USA). After the incubation periods, $10 \mu \mathrm{l}$ of MTT reagent $(5 \mathrm{mg} / \mathrm{ml}$ in PBS) was added into each well and cells were incubated at $37^{\circ} \mathrm{C}$ for $3 \mathrm{~h}$ to allow the MTT cleavage to occur. The reaction was then stopped with $100 \mu 1$ isopropanol with $0.04 \mathrm{~N}$ hydrochloric acid $(\mathrm{HCl})$. The absorbance was measured within an hour, on a multiplate reader (Thermo Labsystems Multiskan spectrum, UV/Visible Microplate Reader, USA) with a test wavelength of $570 \mathrm{~nm}$ and a reference wavelength of $630 \mathrm{~nm}$. For cell growth analysis, 7,500 cells were seeded in $100 \mu 1$ medium into each well of 96-well plates and the MTT test was performed daily as above.

Isolation of chemoresistant cells. HT29 and HCT116 cells were seeded at a density of $10^{6}$ cells $/ 57 \mathrm{~cm}^{2}$ plates and were then continuously exposed to oxaliplatin $(10 \mu \mathrm{M})$ or docetaxel $(5 \mathrm{nM})$.

RNA extraction and reverse transcription-polymerase chain reaction $(R T-P C R)$. Total RNA from parental and chemoresistant cells were extracted using NucleoSpin RNA II columns according to the manufacturer's instructions (Macherey-Nagel, France). Two micrograms of total RNA were used for cDNA synthesis with random hexamers and reverse transcription was performed with the M-MULV reverse transcriptase (NEB Biolabs, France) in a final volume of $25 \mu \mathrm{l}$. For PCR, $2 \mu \mathrm{l}$ of cDNA was used with primers designed using the 'Primer 3 Plus' software (the primer sequences will be provided upon request). The thermal cycling conditions were $94^{\circ} \mathrm{C}$ for $5 \mathrm{~min}$, followed by $23-35$ cycles at $94^{\circ} \mathrm{C}$ for $30 \mathrm{sec}, 59-61^{\circ} \mathrm{C}$, for $50 \mathrm{sec}$ and $72^{\circ} \mathrm{C}$ for $1 \mathrm{~min}$, and a final extension at $72^{\circ} \mathrm{C}$ for $5 \mathrm{~min}$. The housekeeping GAPDH or P0 genes were used as controls. The PCR products were visualized on $2 \%$ agarose gels. Reactions were run in three independent experiments.

Quantitative real-time PCR. The differential expression of all genes was analyzed by real-time PCR (ABI 7000, Applied Biosystems, France). PCR was performed with the Power SYBR-Green PCR Master Mix, according to the manufacturer's instructions (Applied Biosystems). All conditions were normalized relative to the GAPDH control transcript. The results were analyzed using the $2^{-\Delta \Delta \mathrm{Ct}}$ method (27).

Total protein extraction and western blotting. Cells were harvested, washed in PBS and homogenized in lysis buffer (1\% SDS, $1 \mathrm{mM} \mathrm{Na} \mathrm{VO}_{4}, 10 \mathrm{mM}$ Tris $\mathrm{pH}$ 7.4) containing protease inhibitor cocktail (Roche, Meylan, France) and kept for $20 \mathrm{~min}$ on ice. Genomic DNA was sheared by repeated passing of the extracts through 25-gauge needles and then centrifuged at $4200 \mathrm{~g}$, for $1 \mathrm{~min}$. Protein quantification was carried out using the Bio-Rad DC Protein Assay system and the absorbance was measured within one hour on a multiplate reader (Thermo Labsystems Multiskan spectrum, UV/Visible Microplate Reader, USA) at $750 \mathrm{~nm}$. Fifty micrograms of protein extracts were boiled in Laemmli buffer for $5 \mathrm{~min}$, separated by SDS-PAGE using 8\% (MDR1 and E-cadherin) or $12 \%$ (ALDH1A1) polyacrylamide gels and transferred onto a polyvinylidene fluoride membrane (GE Healthcare, France) by electroblotting. Protein extracts used for detecting MDR1 were not boiled. Membranes were saturated using Sea Block Blocking Buffer (Thermo Scientific, France) for $1 \mathrm{~h}$ at room temperature. Primary antibodies MDR1, ALDH1A1 
(Cell Signaling Technology, USA), E-cadherin and Hsc70 (Santa Cruz Biotechnology, USA) were diluted in blocking buffer (Odyssey LI-COR Biosciences, USA), containing $0.1 \%$ Tween-20 ${ }^{\circledR}$. Membranes were incubated with the suitable primary antibody, at $4^{\circ} \mathrm{C}$ overnight, then washed four times with PBS $/ 0.1 \%$ Tween-20 and incubated with the infrared absorbing secondary antibody (Odyssey ${ }^{\circledR}$ ) for $1 \mathrm{~h}$ at room temperature. Membranes were washed again and protein bands revealed using the Odyssey-LI-COR imaging system.

Cell cycle and flow cytometry analysis. Cell cycle distribution of parental and resistant cells was determined using the BD Accuri C6 flow cytometer (BD Biosciences, USA). Cells were plated at a density of $10^{6}$ cells $/ 57 \mathrm{~cm}^{2}$ plates and cultured for $48 \mathrm{~h}$ before analysis. Under these conditions, the cells were in the log phase of the growth cycle. Cells were trypsinized and centrifuged. The pellet was suspended in $1 \mathrm{ml}$ of $70 \%$ cold ethanol $\left(-20^{\circ} \mathrm{C}\right)$ and incubated for $\geq 2 \mathrm{~h}$ at $-20^{\circ} \mathrm{C}$. After this incubation, cells were washed twice with PBS and each pellet was suspended in $500 \mu \mathrm{l}$ of a PBS buffer containing $0.2 \%$ $\mathrm{NP} 40$ and $0.5 \mathrm{mg} / \mathrm{ml}$ of RNase A. At this point, cells were incubated at room temperature for $15 \mathrm{~min}$ and then on ice for $10 \mathrm{~min}$. Finally, $50 \mu \mathrm{g} / \mathrm{ml}$ propidium iodide (Sigma-Aldrich, USA) was added. Non-labeled corresponding cells served as gating controls.

Anchorage-independent growth assay. Soft agar assays were performed to determine the ability of parental and chemoresistant cells to grow under anchorage-restricting conditions. Each well of a 6-well plate was coated with $1 \mathrm{ml}$ of the corresponding medium with $1 \mathrm{ml}$ of $1 \%$ SeaKem agarose (Lonza, USA). After $20 \mathrm{~min}$ of incubation at $37^{\circ} \mathrm{C}$, suspensions of 500 cells were added in $750 \mu 1$ of medium with $250 \mu 1$ of $1 \%$ SeaKem agarose. Cells were incubated for 18 days under standard conditions $\left(37^{\circ} \mathrm{C}, 5 \% \mathrm{CO}_{2}\right)$ in $300 \mu 1$ medium. After the incubation period, cells were examined by stereomicroscopy and the number of colonies was counted in each well.

Cell proliferation. The proliferation rate of the parental and resistant cells was analyzed over a 6-day culture period. For this, 24,000 cells per well were seeded in 6-well plates. Every day, 3 wells per condition were counted using the BD Accuri C6 flow cytometer's cell counting function. Briefly, the supernatant was harvested and cells washed with PBS. Then, cells were trypsinized with $300 \mu \mathrm{l}$ of $0.05 \%$ trypsin/EDTA per well. The single cell-suspensions were washed twice with PBS, and suspended in a final volume of $150 \mu \mathrm{l}$ PBS. The total volume was passed through the cytometer and the cell number was counted directly.

Wound-healing assay. Parental and resistant cells were seeded in 6-well plates and allowed to adhere and spread to give a confluent monolayer. At this point, a straight line was made with a p200 pipette tip to create a scratch (wound). Reference points were made with an ultrafine tip marker. Cells were then washed gently with PBS and cultured in their corresponding medium for the period of the assay. Cells were observed using an inverted Zeiss Axio Vert.A1 microscope (x5) (Carl Zeiss, Germany). Photos were taken every day on exactly the same field, with the microscopy camera Axiocam ERc 5s Rev 2.0
HT29

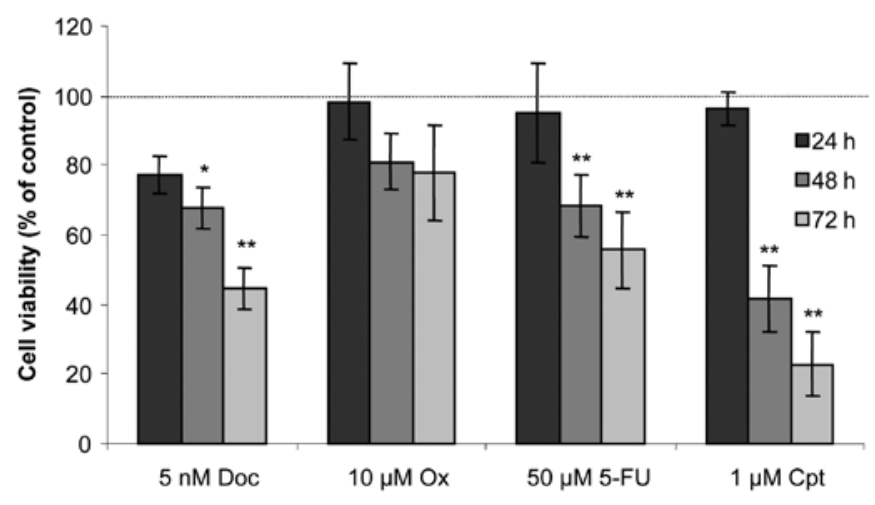

HCT116

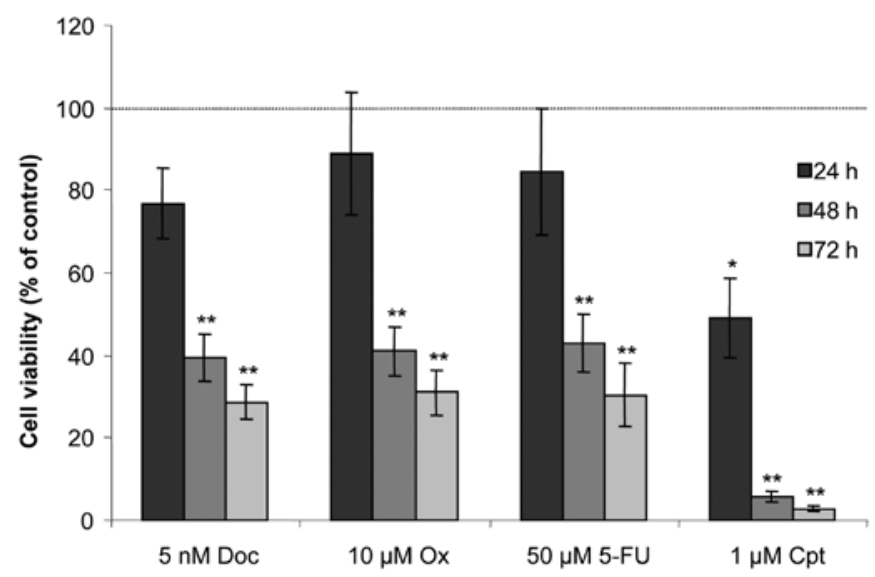

Figure 1. Cell viability of HT29 and HCT116 cells using the MTT assay. Cell viability (\% of control) was measured using the MTT test after exposure of the HT29 and HCT116 cells to $5 \mathrm{nM}$ docetaxel (Doc), $10 \mu \mathrm{M}$ oxaliplatin (Ox), $50 \mu \mathrm{M} 5$-fluorouracil (5-FU) or $1 \mu \mathrm{M}$ camptothecin (Cpt), for 24,48 or $72 \mathrm{~h}$. ${ }^{*} \mathrm{p}<0.05,{ }^{* *} \mathrm{p}<0.01$ (Student's t-test).

(Zeiss), starting from the day the scratch was made (day 0). The reference mark was left outside the captured field, and scratch sizes were similar in the parental and resistant cells at day 0 . The images acquired for each condition were analyzed using Zen Lite 2011 software. The distance $(\mu \mathrm{m})$ between the two sides of the scratch was measured every day, according to ref. 28 .

Statistical analysis. Statistical significance was determined by Student's t-test. p-values $<0.05$ were considered as statistically significant.

\section{Results}

Short-term cell viability analysis. In order to determine their drug sensitivity, HT29 and HCT116 cells were exposed to $5 \mathrm{nM}$ docetaxel, $10 \mu \mathrm{M}$ oxaliplatin, $50 \mu \mathrm{M} 5$-fluorouracil or $1 \mu \mathrm{M}$ camptothecin for 24,48 or $72 \mathrm{~h}$. Cell viability was assessed using the MTT test (Fig. 1). HT29 cells displayed nearly $80 \%$ viability after docetaxel exposure for $24 \mathrm{~h}$ and essentially no sensitivity to the three other molecules. After 48- and 72-h treatment, cell viability decreased significantly in response to docetaxel (68 and 45\%, respectively), 5 -fluorouracil 

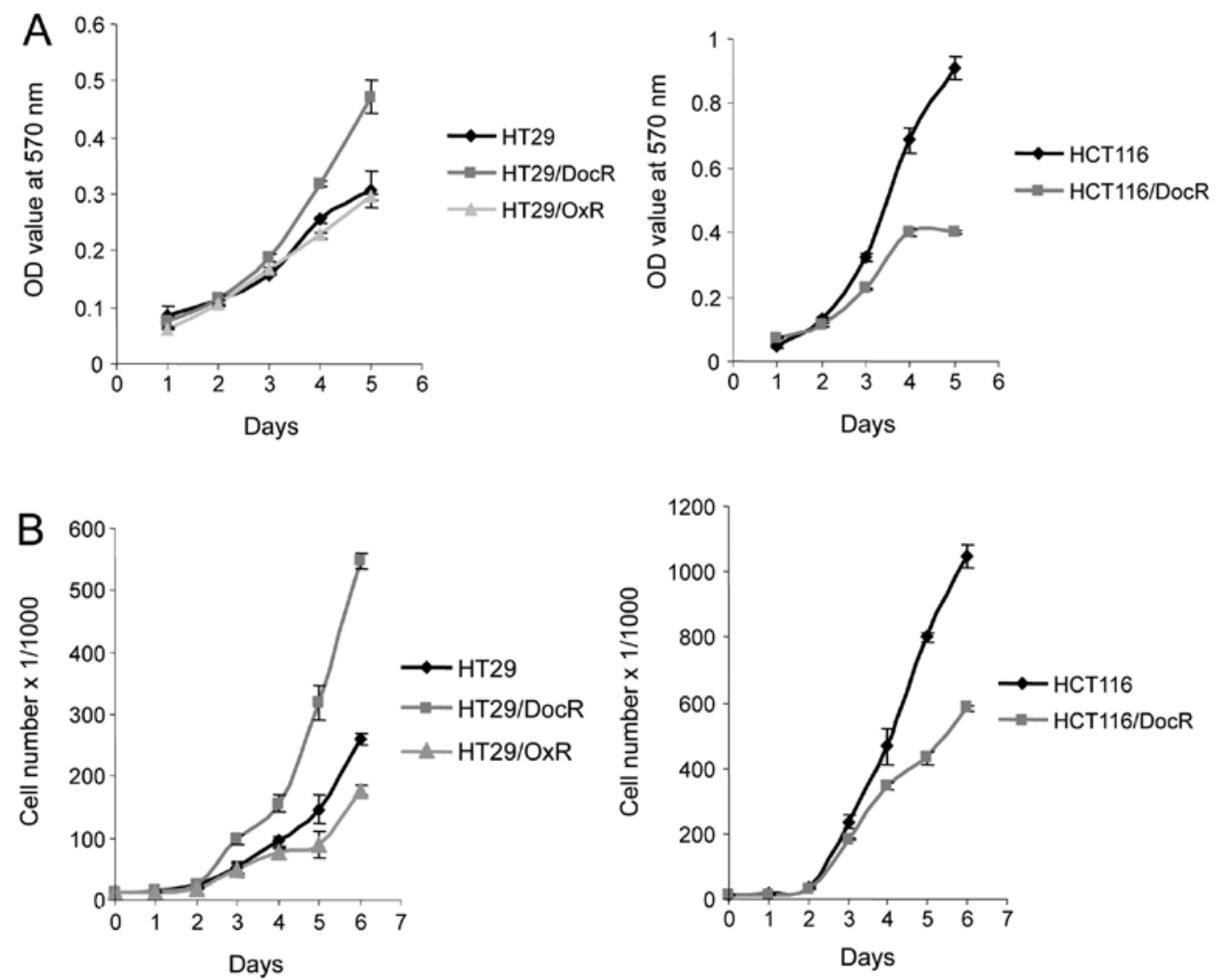

Figure 2. Growth of parental and resistant cells. (A) MTT analysis of proliferation rates. Chemoresistant cells were compared to the corresponding parental cells. (B) Flow cytometry analysis. Cell counting of parental and resistant cells. Both methods have been used in two independent experiments with similar results. The figure is from one experiment for both (A) and (B).

A
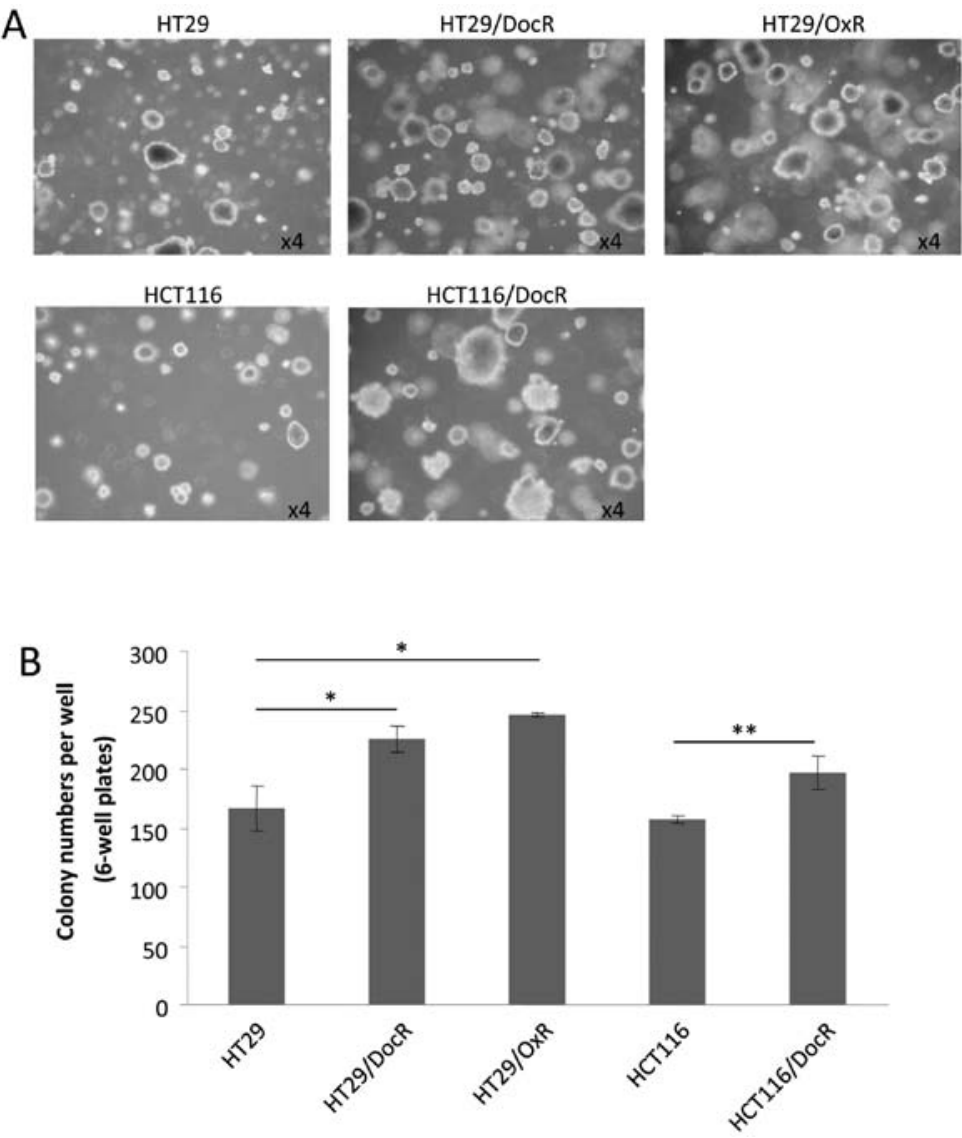

Figure 3. Colony formation. Resistant and parental cells were grown in 3D, in 0.5\% agarose. (A) Phase contrast microphotographs of spheroids (x4). (B) Colony numbers were compared (Student's t-test, ${ }^{*} \mathrm{p}<0.05,{ }^{* *} \mathrm{p}<0.01$ ). 

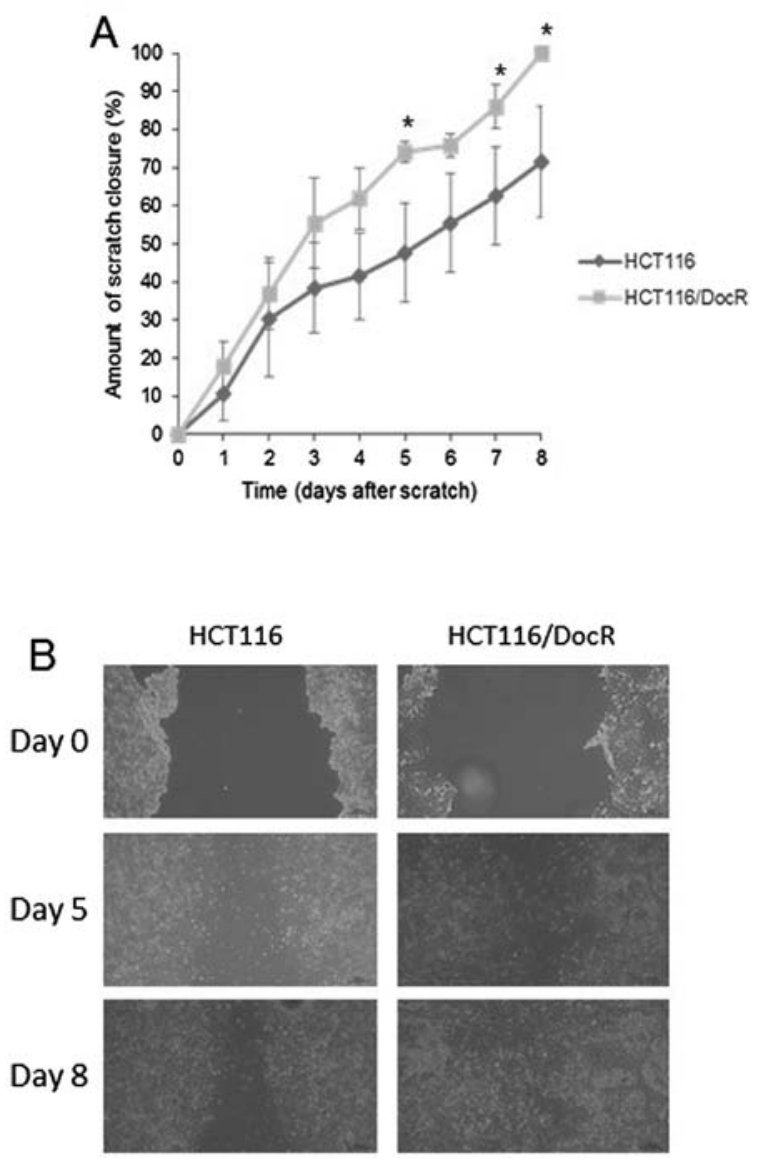

Figure 4. Wound-healing assay. (A) Percentage of wound closure of HCT116/ DocR cells compared to HCT116 parental cells. The assays were performed in three independent experiments with similar results (Student's t-test, "p $<0.05$ ). (B) Representative images of scratch experiments. Images were taken using an Axiocam ERc 5s Rev 2.0 (Zeiss) microscopy camera.

(68 and 56\%, respectively) or camptothecin (42 and $23 \%$, respectively). Oxaliplatin reduced cell viability by $20 \%$ after $72 \mathrm{~h}$. By contrast, HCT116 cells were sensitive to the four molecules at $24 \mathrm{~h}$, with $77,89,85$ and $49 \%$ viability for docetaxel, oxaliplatin, 5-fluorouracil and camptothecin, respectively. For the 48- and 72-h conditions, HCT116 cell viability decreased even further with $29,31,30$ and $3 \%$ viability at $72 \mathrm{~h}$ for docetaxel, oxaliplatin, 5 -fluorouracil and camptothecin, respectively.

Isolation of drug-resistant cells. To determine the effects of drug resistance on the cellular phenotype, we selected HCT116 and HT29-resistant derivatives. Although we could not isolate camptothecin or 5-fluorouracil-resistant cells, we successfully recovered docetaxel $(5 \mathrm{nM})$ or oxaliplatin $(10 \mu \mathrm{M})$-resistant cell populations following 2 months of continuous exposure to either drug, after which no more signs of cell death were observed. Stably resistant cell populations were isolated after 7-9 weeks.

Growth of resistant cells. Growth of the drug-resistant cells was analyzed over 5- or 6-day periods. We first measured the in vitro proliferation rate of parental and resistant cells using the MTT cell viability assay. In parallel, the proliferation rate of the cells was assessed using the cell counting feature of the BD accury C6 flow cytometer. Both methods gave similar results for the general trend of the growth curves (Fig. 2). The proliferation rate of the HT29/DocR cells was higher than that of the parental cells. By contrast, HCT116/DocR cells grew more slowly than HCT116 parental cells. In addition, HT29/ OxR cells grew somewhat more slowly than HT29 parental cells.

Colony formation of chemoresistant cells. A phenotypic characteristic of CSC is their ability to grow as colonospheres or spheroids, which can be evaluated in presence of agarose, i.e., when no adhesion to the plate is possible. Both the parental and the three resistant cell lines generated spheres after 18 days of incubation. However, chemoresistant cells produced essentially larger spheroids (Fig. 3A). Moreover, the number of spheroids was significantly higher for the resistant cells (Fig. 3B). HT29 cells formed on average 177 spheroids, versus 220 (124\%) and 246 (139\%) spheroids, respectively for HT29/ DocR and HT29/OxR cells $(\mathrm{p}<0.05)$. For HCT116 cells, an average 156 spheres were counted compared to 190 (122\%) spheres for HCT116/DocR cells $(\mathrm{p}<0.01)$.

Wound-healing assay. In order to assay the migration ability of resistant cells, an indicator of the stemness-like phenotype, we used the wound-healing assay method (29). Parental and resistant cells were cultured in 6-well plates, and a gap was made upon scratching the plate surface after cells had reached confluency. Images were captured daily and the distance (in $\mu \mathrm{m}$ ) between the two edges of the scratch was measured. For the HT29 cells, no significant difference was recorded in the percentage $(\%)$ of scratch closure between the parental (49.9\%) and resistant cells (48 and 49.8\% for HT29/DocR and HT29/OxR cells, respectively - data not shown). By contrast, the HCT116/DocR cells were able to achieve a complete closure of the scratch $(100 \%)$ at day 8 post-scratch while the HCT116 parental cells had closed only $71 \%$ of the gap on the same day (Fig. 4).

Cell cycle distribution. The effects of chemo-resistance on the cell cycle were evaluated using flow cytometry analysis. Genes implicated in cell cycle or apoptosis control were studied by RTqPCR. No change in cell cycle distribution was observed in HT29/DocR cells (Fig. 5). However, the proportion of HCT116/DocR cells (61\%) in the G0/G1 phase was higher than that of the parental cells (46\%), and fewer cells were in the $\mathrm{S}$ (20 vs $28 \%$ in parental cells) and G2/M phases (19 vs 26\%). Accordingly, the level of cyclin B1, which controls the G2/M transition, was decreased in HCT116/DocR cells, which correlated with the cell cycle distribution of the cells (Table I) and the slowest growth. For the HT29/OxR cells, the fraction of cells in G2/M was decreased (from 29 to $22 \%$ ) and that in S phase was increased (from 15 to 21\%) (Fig. 5). Surprisingly, cyclin B1 was increased while the fraction of HT29/OxR cells in $\mathrm{G} 2 / \mathrm{M}$ was decreased, suggesting that some other mechanism may be involved in downregulating HT29/OxR cells growth. Cyclin D1, which controls progression through the G1 phase, showed a 1.7-1.8-fold increase in the three resistant cell lines. The cyclin-dependent kinase inhibitor 1 (p21), which acts as a negative regulator of cell cycle progression during the G1 and 

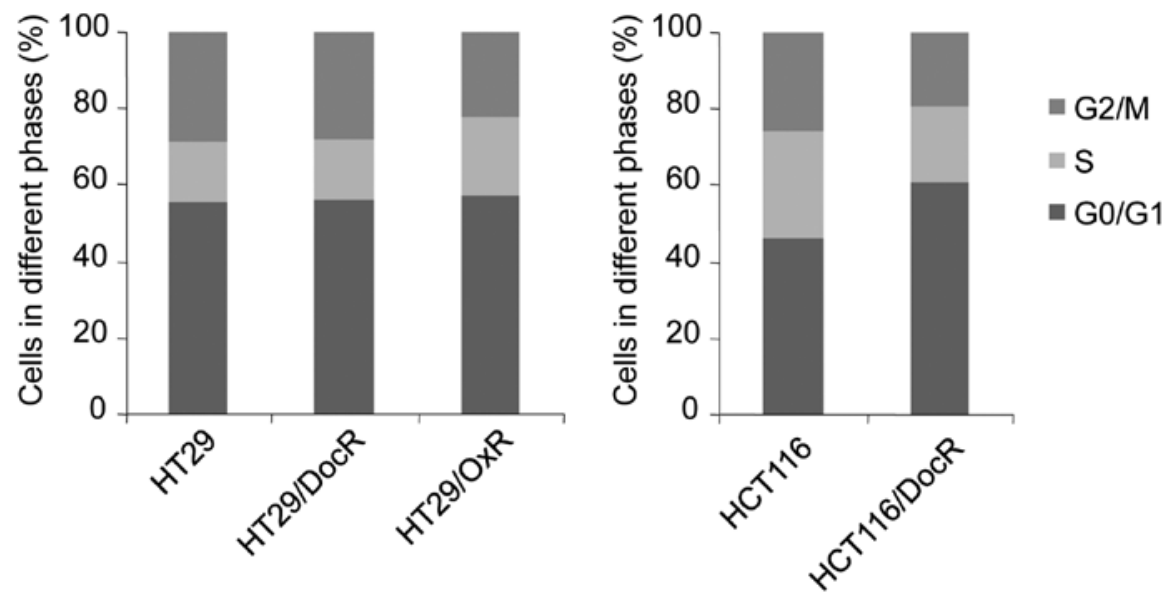

Figure 5. Cell cycle and marker gene analysis. Flow cytometry analyses of the cell cycle distribution.

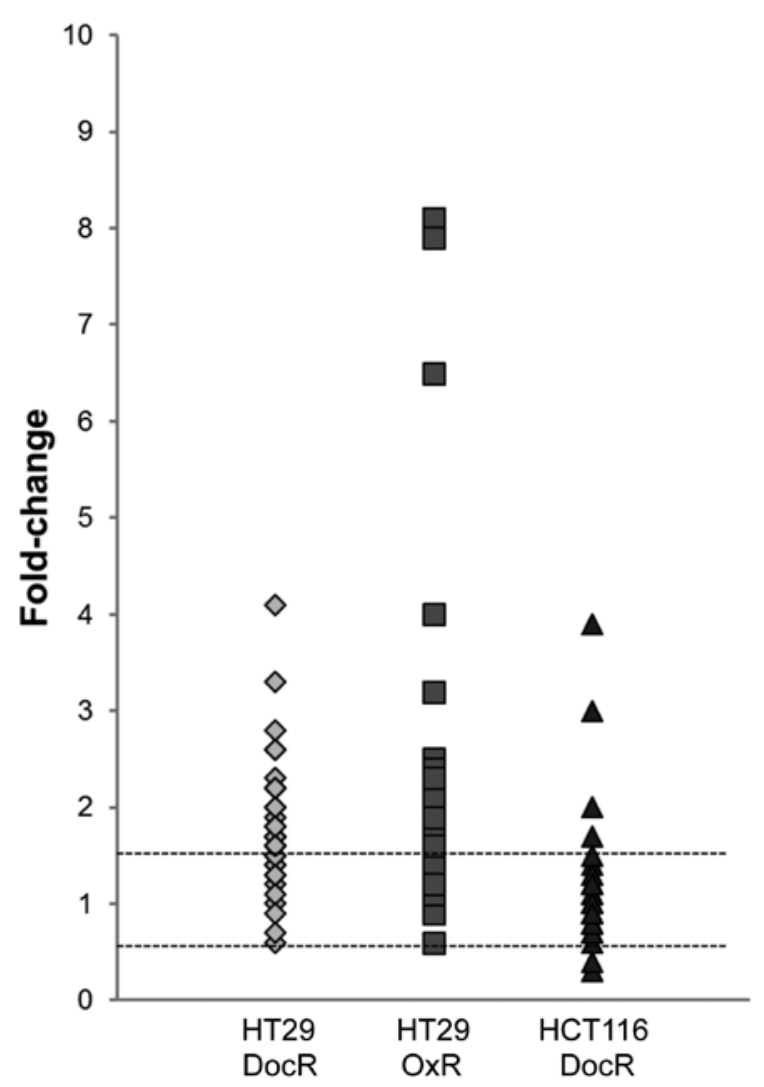

Figure 6. Distribution of marker genes among the three resistant cell populations. The relative level of the marker mRNAs is indicated as fold-changes in comparison with the parental drug-sensitive cell populations. Fold-change limits are indicated with horizontal dashed lines (minimum increase set at 1.5 -fold and minimum decrease set at 0.5 -fold).

$\mathrm{S}$ phases, was overexpressed in the resistant cells with a 2.6-, an 8.1- and a 3-fold change in the HT29/DocR, HT29/OxR and HCT116/DocR cells, respectively (Table I). The cyclindependent kinase inhibitor 1B (p27) was marginally increased (1.6- and 1.4-fold in HT29/DocR and OxR cells, respectively). Survivin, which opposes apoptosis, was overexpressed in HT29/OxR cells (3.2-fold).

To follow the characterization of the resistant cell phenotypes, we selected a number of specific markers associated with drug resistance, colon cancer differentiation and cancer stemness. A global survey of these markers showed that drugresistant HT29 cells expressed most of them at higher levels than parental cells ( 24 and 25 overexpressed out of 34 markers for HT29/DocR and HT29/OxR, respectively). By contrast, most of these markers remained unchanged in HCT116/ DocR in comparison with parental cells (24 unchanged out of 34 markers). CD26, CD166, Cyclin D1, p21 and MDR1 were the five genes commonly upregulated between all three drug-resistant cell populations (Table I and Fig. 6).

Drug resistance and expression of chemo-resistance-related markers. The expression level of genes potentially involved in oxaliplatin or docetaxel resistance was analyzed by RT-PCR, RT-qPCR and/or western blot analyses. The three resistant cell populations exhibited higher levels of MDR1, a member of the superfamily of ATP-binding cassette (ABC) transporters responsible for decreased drug accumulation in multidrugresistant cells. A 3.3-fold-change for the HT29/DocR cells, an 8.1-fold-change in the HT29/OxR cells and a 22-fold-change increase for the HCT116/DocR cells were obtained (Table I). However, the western blot analysis showed overexpression of the MDR1 protein in HCT116/DocR cells, but not in HT29resistant cells, possibly because of a very low basal expression level (Fig. 7). The level of ATP-binding cassette sub-family G member 2 (ABCG2) mRNA was increased in HCT116/DocR cells, but declined in HT29/DocR and HT29/OxR cells. The multidrug resistance-associated protein 2 (MRP2), which was reported to be involved in the response to oxaliplatin (30), was increased in HT29/OxR cells but decreased in HCT116/DocR cells. The level of the organic anion transporting polypeptide 2B1 (OATP2B1), which contribution to docetaxel uptake and clearance is not well established (31), was evaluated. No change was registered for the HT29/OxR cells or the HCT116/ DocR cells, while a 1.6-fold increase was observed in HT29/ DocR cells. The copper transporter ATP7A that pumps out platinum compounds (32), was increased in some tumors, including CRC, and slightly increased in the HT29/DocR and HT29/OxR cells. ATP7B levels were increased only in HT29/ DocR. Drug uptake was evaluated with the copper transporter hCTR1, but no significant difference was observed in the resis- 
Table I. RT-qPCR analyses of marker genes in drug-resistant cells, cell cycle and apoptosis-related genes, differentiation markers and the CSC potential marker expression. ${ }^{a}$

\begin{tabular}{|c|c|c|c|}
\hline \multirow[b]{2}{*}{ Gene } & \multicolumn{3}{|c|}{ Fold change versus levels in parental cell lines } \\
\hline & HT29 DocR & HT29 OxR & HCT116 DocR \\
\hline \multicolumn{4}{|l|}{ Drug resistance } \\
\hline MDR1 & $3.3 \pm 1.4^{\mathrm{b}}$ & $8.1 \pm 2.3^{\mathrm{b}}$ & $22 \pm 5.8^{b}$ \\
\hline ABCG2 & $0.6 \pm 0.1^{\mathrm{c}}$ & $0.6 \pm 0.2$ & $3.9 \pm 0.6^{\mathrm{c}}$ \\
\hline MRP2 & $1.9 \pm 0.7$ & $4 \pm 1^{c}$ & $0.3 \pm 0.1^{\mathrm{c}}$ \\
\hline OATP2B1 & $1.6 \pm 0.5$ & $0.9 \pm 0.2$ & $0.9 \pm 0.3$ \\
\hline ATP7A & $1.7 \pm 0.2^{\mathrm{c}}$ & $1.6 \pm 0.3^{\mathrm{b}}$ & $0.7 \pm 0.1^{\mathrm{b}}$ \\
\hline ATP7B & $2.2 \pm 0.5^{\mathrm{c}}$ & $1.1 \pm 0.3$ & $1.4 \pm 0.5$ \\
\hline hCTR1 & $1 \pm 0.1$ & $1.5 \pm 0.6$ & $1.1 \pm 0.1$ \\
\hline MT2A & $1.2 \pm 0.4$ & $2.4 \pm 0.4^{\mathrm{c}}$ & $0.96 \pm 0.01^{\mathrm{c}}$ \\
\hline $\mathrm{GST} \pi$ & $1.1 \pm 0.1^{\mathrm{b}}$ & $1.2 \pm 0.1^{\mathrm{b}}$ & $1.3 \pm 0.4$ \\
\hline CYP 3A5 & $1.4 \pm 0.2^{\mathrm{c}}$ & $1.1 \pm 0.2$ & $1 \pm 0.4$ \\
\hline XPD & $1.5 \pm 0.05^{\mathrm{c}}$ & $1.2 \pm 0.03^{\mathrm{c}}$ & $0.9 \pm 0.2$ \\
\hline CSB & $1.8 \pm 0.1^{\mathrm{c}}$ & $1.8 \pm 0.1^{\mathrm{c}}$ & $1.2 \pm 0.4$ \\
\hline XPF & $1.7 \pm 0.3^{c}$ & $1.9 \pm 0.1^{\mathrm{c}}$ & $1 \pm 0.2$ \\
\hline SRPK1 & $0.9 \pm 0.1$ & $1.6 \pm 0.4^{b}$ & $1 \pm 0.2$ \\
\hline $\mathrm{NF} \kappa \mathrm{B} 1$ & $1.4 \pm 0.1^{\mathrm{c}}$ & $1.5 \pm 0.1^{\mathrm{c}}$ & $1.1 \pm 0.2$ \\
\hline \multicolumn{4}{|l|}{ Cell cycle } \\
\hline Cyclin B1 & $1.3 \pm 0.3$ & $2.5 \pm 0.2^{\mathrm{c}}$ & $0.6 \pm 0.1^{\mathrm{c}}$ \\
\hline Cyclin D1 & $1.7 \pm 0.2^{\mathrm{c}}$ & $1.8 \pm 0.3^{\mathrm{b}}$ & $1.7 \pm 0.6$ \\
\hline p21 & $2.6 \pm 0.7^{b}$ & $8.1 \pm 1.2^{\mathrm{c}}$ & $3 \pm 0.9^{b}$ \\
\hline $\mathrm{p} 27$ & $1.6 \pm 0.5$ & $1.4 \pm 0.2^{\mathrm{b}}$ & $0.8 \pm 0.2$ \\
\hline Survivin & $1.3 \pm 0.3$ & $3.2 \pm 1.3$ & $0.8 \pm 0.1^{\mathrm{b}}$ \\
\hline \multicolumn{4}{|l|}{ Differentiation } \\
\hline E-cadherin & $2 \pm 0.5^{\mathrm{b}}$ & $1.8 \pm 0.3^{c}$ & $1.2 \pm 0.2$ \\
\hline TGF $\beta 1$ & $2.6 \pm 0.4^{\mathrm{c}}$ & $2 \pm 0.4^{\mathrm{c}}$ & $1.2 \pm 0.1^{\mathrm{c}}$ \\
\hline TGF $\beta 2$ & $0.7 \pm 0.2$ & $1.2 \pm 0.2$ & $0.4 \pm 0.2^{\mathrm{b}}$ \\
\hline Villin & $1.5 \pm 0.3^{\mathrm{b}}$ & $1.2 \pm 0.1^{\mathrm{c}}$ & Undetected \\
\hline$\beta 1$ catenin & $1.7 \pm 0.3^{\mathrm{c}}$ & $2.4 \pm 0.4^{\mathrm{c}}$ & $0.7 \pm 0.2^{\mathrm{b}}$ \\
\hline$\alpha 1$ catenin & $1.6 \pm 0.3^{\mathrm{b}}$ & $2.1 \pm 0.4^{\mathrm{b}}$ & $0.8 \pm 0.1^{\mathrm{b}}$ \\
\hline \multicolumn{4}{|l|}{$\begin{array}{l}\text { CSC potential } \\
\text { markers }\end{array}$} \\
\hline CD26 & $2.3 \pm 0.4^{\mathrm{c}}$ & $2 \pm 0.6$ & $2 \pm 0.3^{c}$ \\
\hline CD133 & $2.8 \pm 0.7^{\mathrm{c}}$ & $2.1 \pm 0.6^{\mathrm{b}}$ & $1 \pm 0.3$ \\
\hline CD166 & $4.1 \pm 0.9^{c}$ & $7.9 \pm 1.9^{\mathrm{c}}$ & $1.5 \pm 0.3^{\mathrm{b}}$ \\
\hline EpCAM & $1.8 \pm 0.1^{\mathrm{c}}$ & $2.3 \pm 0.4^{\mathrm{c}}$ & $0.9 \pm 0.1$ \\
\hline EPHB2 & $2.2 \pm 0.8$ & $6.5 \pm 0.8^{c}$ & $1.3 \pm 0.2$ \\
\hline Oct4 & $2 \pm 0.6^{\mathrm{b}}$ & $1.6 \pm 0.1$ & $1 \pm 0.3$ \\
\hline Myc & $2.2 \pm 0.4^{\mathrm{b}}$ & $1.9 \pm 0.4^{\mathrm{b}}$ & $0.9 \pm 0.03^{b}$ \\
\hline ITGB1 & $1.6 \pm 0.4$ & $3.2 \pm 0.04^{\mathrm{c}}$ & $1.2 \pm 0.2$ \\
\hline ALDH1A1 & $0.8 \pm 0.01^{\mathrm{c}}$ & $0.6 \pm 0.2$ & Undetected \\
\hline
\end{tabular}

${ }^{\text {aa }}$ esults were normalized to GAPDH. The experiments were performed three or four times for each PCR primer pair. Statistical significance (Student's t-test, ${ }^{\mathrm{b}} \mathrm{p}<0.05,{ }^{\mathrm{c}} \mathrm{p}<0.01$ ).

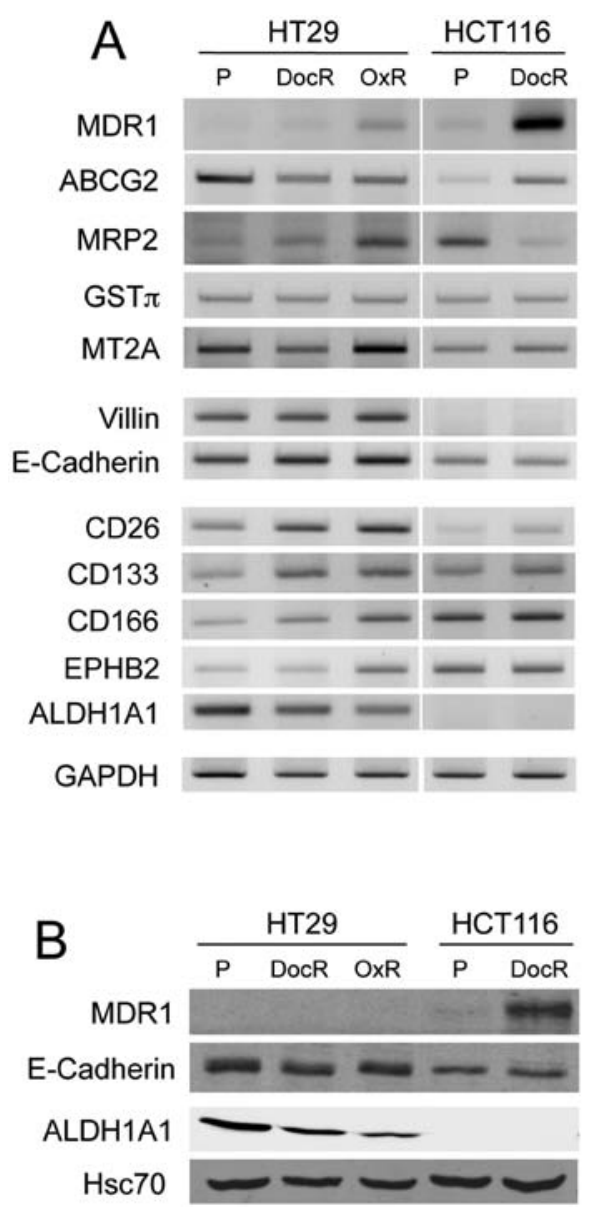

Figure 7. Comparative expression of drug-resistance-related markers, differentiation and CSC potential markers in parental and chemo-resistant cells. (A) RT-PCR analyses of MDR1, ABCG2, MRP2, GST $\pi$, MT2A, villin, E-cadherin, CD26, CD133, CD166, EPHB2 and ALDH1A1 expression. GAPDH was used as control. (B) Western blot analysis of MDR1, E-cadherin, ALDH1A1 expression. Hsc70 served as protein loading control. P, parental; drug-sensitive cells; DocR, docetaxel (5 nM)-resistant cells; OxR, oxaliplatin $(10 \mu \mathrm{M})$-resistant cells.

tant cells. We looked also at expression of drug detoxification and drug-metabolizing enzymes. Metallothionein 2A (MT2A) was increased (2.4-fold) in HT29/OxR cells. Glutathione-Stransferase $\pi$ (GST $\pi$ and cytochrome CYP3A5 levels showed no change in the resistant cells. Since DNA repair is one of the predominant events that occur in resistance to platinum agents, we analyzed expression of xeroderma pigmentosum group D and group F (XPD and XPF) and cocaine syndrome group $\mathrm{B}$ (CSB), members of the nucleotide excision repair (NER) pathway (33). No change was observed in HCT116/ DocR mRNA levels of these genes, whereas CSB and XPF and, to a lower extent, XPD, were increased (1.5- to 1.9-fold) in HT29/DocR and HT29/OxR cells, although docetaxel does not trigger DNA damage. Finally the nuclear factor NFкB1 that plays a role in the inhibition of apoptosis and the induction of resistance to various chemotherapeutic agents (34), was slightly overexpressed in HT29 (1.4- to 1.5-fold), but not in HCT116-resistant cells.

Effect of chemo-resistance on the expression of differentiation markers. Solid cancer resistance to therapy has been linked to the existence of CSC that may be mostly resistant to anti- 


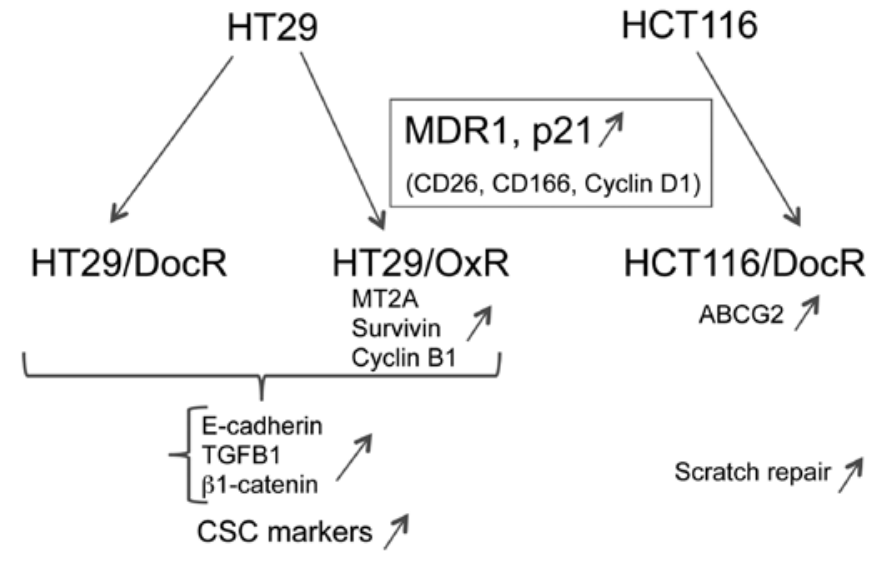

Colonospheres

Figure 8. Schematic representation of the results of this study.

cancer treatments. We used RT-PCR, RT-qPCR and western blot analyses to survey differentiation markers. E-cadherin, which plays a role in cell-cell adhesion, is reportedly associated with the epithelial to mesenchymal transition (EMT), a characteristic feature of cancer-associated aggressiveness, when underexpressed (35). However, E-cadherin mRNA increased by 2 - and 1.8 -fold in HT29/DocR and OxR cells (Table I), while no change was detected at the protein level (Fig. 7), and remained unchanged in HCT116/DocR cells. In addition, expression of TGF $\beta 1$, which is involved in metastasis and invasion, was increased in HT29/DocR and HT29/OxR cells, but not in HCT116/DocR cells. TGF 32 was reduced in HCT116/DocR cells. The tissue-specific actin-binding protein villin, which is associated with invasion and aggressiveness in cancers, was slightly overexpressed in HT29/ DocR cells. $\beta 1$ catenin and $\alpha 1$ catenin that are implicated in EMT in cancer, were overexpressed in both HT29/DocR and HT29/OxR cells, but no change in expression occurred in HCT116/DocR cells.

Chemo-resistance and expression of CSC markers. We next analyzed the expression of several CSC markers (Table I). Dipeptidyl peptidase-4 (DPP4), also known as CD26 (cluster of differentiation 26) (36) is a stem cell-inducing gene; it was overexpressed in HT29/DocR with a 2.3-fold-change, likewise in HT29/OxR cells and HCT116/DocR cells with a 2-foldchange. We next studied the expression of CD133 and CD166, trans-membrane glycoproteins implicated in cell adhesion and migration (37,38). CD133 mRNA levels increased by 2.8 - and 2.1-fold in HT29/DocR and HT29/OxR cells, respectively, but did not change in HCT116/DocR cells. CD166 expression was strongly increased in HT29/DocR (4.1-fold) and HT29/OxR (7.9-fold) cells, whereas it was increased only 1.5 -fold in HCT116/DocR cells. The epithelial cell adhesion molecule (EpCAM) was overexpressed (1.8- to 2.3-fold) in the HT29resistant cells, but not in HCT116-resistant cells. The ephrin type-B receptor 2 (EPHB2) gene, which encodes a receptor with tyrosine kinase activity that characterizes colorectal cancer stem cells, was also overexpressed in HT29/DocR (2.2-fold) and HT29/OxR (6.5-fold) cells, but not in HCT116/ DocR cells (Table I and Fig. 7). The octamer-binding transcription factor 4 (Oct-4) is a transcription factor essential for maintenance of the self-renewal, or pluripotency of undifferentiated embryonic stem cells (37). Its level was increased in the HT29/DocR (2-fold) and HT29/OxR (1.6-fold) cells, but not in HCT116/DocR cells. The Myc oncogene, considered as an essential factor in the generation and maintenance of the stemness status (39), was also overexpressed in both HT29/DocR (2.2-fold) and HT29/OxR (1.9-fold) cells, but not in HCT116/DocR cells. Integrin $\beta-1$ (ITG $\beta-1)$ mRNA, which has been shown to play a role in the resistance of hepatic and esophageal carcinoma cells to docetaxel $(40,41)$, showed an increased expression in HT29/DocR (1.6-fold) and HT29/OxR (3.2-fold) cells, again with no noticeable change in HCT116/DocR cells. The serine/arginine protein kinase 1 (SRPK1), involved in phosphorylation-dependent activation of serine/arginine-rich RNA binding proteins, in platinum resistance (42) and in the acquisition of an EMT phenotype (43) showed a 1.6-fold increase in HT29/OxR.

\section{Discussion}

In this study, we set out to analyze the overall phenotype of human colon cancer cells selected for their acquired resistance to the anticancer drugs oxaliplatin and docetaxel. We were successful in isolating drug-resistant HT29 and HCT116 cells following 2-month continuous exposure to the drugs. Short-term drug treatments showed that HCT116 cells were much more sensitive than HT29 cells, possibly due, at least in part, to their higher multiplication rate. Camptothecin was the most toxic for both cell lines after 48 or $72 \mathrm{~h}$. However, we could not isolate camptothecin-resistant cells, presumably because DNA topoisomerase I activity is mandatory. The drug-resistant cells were capable of forming more and larger colonies in agarose-containing medium than naïve cells. This capacity fits well with stem cell properties whereby a cell can expand and give rise to a heterogeneous colony in vitro, under anchorage-independent conditions, resembling that happening during EMT and invasion. In addition, the ability of scratch repair was strongly magnified in HCT116/DocR cells as compared to parental cells, although this was not the case for HT29-resistant cells, making this another clear distinction among the HT29 or HCT116-resistant cells.

Drug metabolism and disposition. Several drug-metabolizing enzymes have been implicated in the metabolism of docetaxel and/or platinum salts $(6,44,45)$. The expression levels of CYP3A5, GST $\pi$ and MT2A were barely changed in the resistant cells, except in HT29/OxR cells where a 2.4-fold increase occurred for MT2A, which agreed with previous reports $(46,47)$ linking the overexpression of MT2A to resistance to platinum drugs.

The multidrug resistance protein 1 (MDR1 or Pgp or ABCB1) is an ATP-dependent efflux pump localized at the cell membrane that plays a role in expulsing a variety of toxic agents. MDR1 is primarily expressed in normal tissues such as the liver, the brain and the gastrointestinal tract, before the initiation of any therapy $(48,49)$. However, it has been linked to a general drug resistance phenotype, as its gene is often ampli- 
fied and/or overexpressed in tumors or in colon CSC $(50,51)$. Docetaxel is mainly eliminated by Pgp-mediated efflux (11). Hence, the resistant phenotype observed here agrees well with an increased expulsion of docetaxel due to overexpression of Pgp in HCT116/DocR. Strikingly, ABCG2 was overexpressed in HCT116/DocR cells only. Although oxaliplatin is not an ABCG2 substrate (21), upregulation of its mRNA has been observed in some oxaliplatin-resistant CRC cells (52). In addition, docetaxel may (53) or may not (21) be an ABCG2 substrate, depending on the study. The MRP2 (encoded by the ABCC2 gene) increase was associated with resistance to oxaliplatin of HT29/OxR, as reported (54). Hence, the main genes potentially involved in oxaliplatin resistance were MDR 1 and MRP2. OATP2B1, although reported to affect the intracellular concentration of several anticancer drugs $(31,45,55,56)$, was only marginally increased in HT29/DocR. No consistent pattern of regulation was observed for the ATP7A, ATP7B and hCTR1 copper transporters, although a 2.2-fold increase in ATP7B levels occurred in HT29/DocR.

DNA repair and signaling. The nucleotide excision repair (NER) pathway is responsible for repairing DNA adducts produced by platinum agents $(57,58)$. Expression of CSB and XPF genes was increased in HT29/OxR cells, in good agreement with the increase in DNA-repair ability and the development of resistance to cisplatin (59). Expression of these genes was also increased in HT29/DocR but not in HCT116/ DocR cells.

As splicing abnormalities frequently occur in cancer (60), we looked at SRPK1, a kinase that phosphorylates, and hence positively controls, the activity of the SR-rich proteins. However, only HT29/OxR cells showed a moderate 1.6-fold increase SRPK1 compared to HT29 parental cells. The nuclear transcription factor $\mathrm{NF \kappa B}$ was reported to mediate tumor progression, metastasis and resistance to drugs (61). $\mathrm{NF} \kappa \mathrm{B}$ is activated in response to many stimuli such as tumor necrosis factor $\alpha$, radiation and chemotherapeutics, including docetaxel (62). This activation leads to inhibition of apoptosis and to resistance to various chemotherapeutic agents (34), including docetaxel. However, only small changes in expression were observed in the DocR cells.

Cell cycle and apoptosis regulation. Distribution of the cells in the different phases of the cycle was measured by flow cytometry. Although only slight modifications were observed for HT29-resistant cells, a higher proportion of HCT116/ DocR cells were recorded in the G0/G1 phase, together with a decreased proportion of cells in the $S$ phase and a lower proportion in the $\mathrm{G} 2 / \mathrm{M}$ phase, in agreement with previous reports (63). Surprisingly, Cyclin B1, which main role is to control the G2/M phase, was increased in the HT29/OxR cells. Cyclin D1, which is required for the progression through the G1 phase, was increased in the three resistant cell populations. The cyclin-dependent kinase inhibitor 1 (p21) that mediates growth arrest was increased strongly in the three resistant cell populations. p21 has also a well-known role in protecting colon cancer cells against a variety of injuries, including those caused by anticancer drugs (64). By contrast, the cyclin-dependent inhibitor 1B (p27), a cell cycle inhibitor, was slightly overexpressed in HT29-resistant cells. Survivin, that inhibits caspase activation, thereby preventing apoptosis, was uniquely increased in HT29/OxR cells.

EMT markers. Resistance to chemotherapeutics has been partly correlated to an EMT phenotype (65). Three major factors associated with EMT, E-cadherin, $\beta$-catenin and $\alpha$-catenin were overexpressed in both HT29-resistant cells, but $\beta$-catenin and $\alpha$-catenin were decreased in HCT116/DocR cells. TGF $\beta$ is a pluripotent cytokine expressed in the colon that promotes invasion and metastasis during advanced stage CRC. The increase of TGF $\beta 1$ was linked to the EMT in a number of solid tumors, including CRC (66). TGF $\beta 1$ level was increased in HT29-resistant cells, while TGF $\beta 2$ was either suppressed or unchanged across all cells. The level of the invasion-associated gene villin was barely changed, although previous reports showed that overexpression of villin was correlated to an aggressive cell phenotype and to EMT (67).

Stem cell markers. Many CSC markers, such as cell surface receptors or transmembrane proteins involved in cell-cell or cell-matrix adhesion, including CD133, EpCAM, CD166, the integrin family, or stem cell inducing genes (Oct-4, CD26) have been reported $(37,68)$. Our data showed that all markers but ALDH1A1 were increased in HT29-resistant cells. ALDH1A1 expression was undetected in HCT116 parental and drug-resistant cells, although, ALDH1A1 was proposed to characterize a subpopulation of cells with tumor-initiating or cancer stem cell properties in several malignancies $(69,70)$. By contrast with HT29-resistant cells, only CD26 and CD166 showed some increase, but a very limited one, in HCT116/ DocR cells. Enhanced expression of CD26 correlated with the associated increase in metastatic capacity and resistance to drugs in CRC (36), and that of CD166, a transmembrane glycoprotein, was previously reported to result in an enhanced cell adhesion and migration (38). EpCAM, a transmembrane glycoprotein involved in cell signaling, migration, proliferation and differentiation (71), was also increased in HT29 drug-resistant derivatives. Similarly, the ephrin type-B receptor (EPHB2), which may be controlled by the Wnt pathway, an event critically required for the progression of colorectal cancer, or Oct-4, a pluripotent stem cell inducer and a self-renewal regulatory factor, which may play a role in the physiology of CSC (72), were also upregulated. Myc plays a central role in regulating proliferation and survival of normal cells and CSC and connects malignancy with stemness (39), was also overexpressed in HT29-resistant cells. Receptors of the $\beta 1$ integrin family are involved in many tumor-promoting activities (73), and overexpression of ITG $\beta$-1 has been reported in hepatocellular carcinoma (HCC) (41) and esophageal squamous cell carcinoma (40). It has been associated with resistance to apoptosis via the activation of a MAP kinase-dependent pathway. For esophageal squamous cell carcinoma, it was suggested that targeting ITG $\beta-1$ could enhance the effect of chemotherapy, particularly in using docetaxel (40).

In conclusion, the isolation of oxaliplatin and/or docetaxelresistant cell populations from 2 different human colon cancer cell lines revealed a number of shared phenotypic traits. Increased ability to form colonospheres was common to HT29 and HCT116 drug-resistant cells, and all cell populations showed increased expression of the CD26, CD166, Cyclin D1, 
p21 and MDR1 genes. However, other markers showed cell line-restricted regulations. Strikingly, differentiation and EMT markers were increased in HT29, but not in HCT116 drug-resistant cells. By contrast, a marked increase in wound repair activity was specific for HCT116/DocR cells, indicating a higher ability to engage into active migration. Our results suggest that better chances to overcome colon cancer resistance, intrinsic or acquired, might be obtained by lowering tumor expressed MDR1 and, possibly, CD26, CD166, Cyclin D1 and p21. In conclusion, the selection of drug-resistant derivatives of HT29 and HCT116 cells led to the isolation of cell populations displaying a few shared but, mostly, unshared phenotypic properties (Fig. 8). This suggests that, in the case of oxaliplatin and docetaxel, the establishment of a drug-resistant phenotype may use different routes, depending on the cancer cell of origin. Taken together, the results presented here indicate that the acquisition of drug resistance by established colon cancer cell lines is only partly associated with the expression of a strict colon cancer stem cell phenotype.

\section{Acknowledgements}

F.E.K. was supported by a fellowship from the French Ministry of Education and Research; this study was supported by the INSERM, Brest University (UBO) and the Ligue Regionale Contre le Cancer (comité du Finistère).

\section{References}

1. Bray F, Ren JS, Masuyer E and Ferlay J: Global estimates of cancer prevalence for 27 sites in the adult population in 2008. Int J Cancer 132: 1133-1145, 2013.

2. Ferlay J, Soerjomataram I, Dikshit R, Eser S, Mathers C, Rebelo M, Parkin DM, Forman D and Bray F: Cancer incidence and mortality worldwide: Sources, methods and major patterns in GLOBOCAN 2012. Int J Cancer 136: E359-E386, 2015.

3. Wang D and Lippard SJ: Cellular processing of platinum anticancer drugs. Nat Rev Drug Discov 4: 307-320, 2005.

4. Barker N, van Es JH, Kuipers J, Kujala P, van den Born M, Cozijnsen M, Haegebarth A, Korving J, Begthel H, Peters PJ, et al: Identification of stem cells in small intestine and colon by marker gene Lgr5. Nature 449: 1003-1007, 2007.

5. Kanwar SS, Yu Y, Nautiyal J, Patel BB and Majumdar AP: The Wnt/beta-catenin pathway regulates growth and maintenance of colonospheres. Mol Cancer 9: 212, 2010.

6. Arnould S, Hennebelle I, Canal P, Bugat R and Guichard S: Cellular determinants of oxaliplatin sensitivity in colon cancer cell lines. Eur J Cancer 39: 112-119, 2003.

7. Ringel I and Horwitz SB: Studies with RP 56976 (taxotere): A semisynthetic analogue of taxol. J Natl Cancer Inst 83: 288-291, 1991.

8. Sternberg CN, ten Bokkel Huinink WW, Smyth JF, Bruntsch V, Dirix LY, Pavlidis NA, Franklin H, Wanders S, Le Bail N and Kaye SB: Docetaxel (Taxotere), a novel taxoid, in the treatment of advanced colorectal carcinoma: An EORTC Early Clinical Trials Group Study. Br J Cancer 70: 376-379, 1994.

9. Lee HH, Leake BF, Teft W, Tirona RG, Kim RB and Ho RH: Contribution of hepatic organic anion-transporting polypeptides to docetaxel uptake and clearance. Mol Cancer Ther 14: 994-1003, 2015.

10. van Herwaarden AE, Wagenaar E, van der Kruijssen CM, van Waterschoot RA, Smit JW, Song JY, van der Valk MA, van Tellingen $\mathrm{O}$, van der Hoorn JW, Rosing $\mathrm{H}$, et al: Knockout of cytochrome P450 3A yields new mouse models for understanding xenobiotic metabolism. J Clin Invest 117: 3583-3592, 2007.

11. Wils P, Phung-Ba V, Warnery A, Lechardeur D, Raeissi S, Hidalgo IJ and Scherman D: Polarized transport of docetaxel and vinblastine mediated by P-glycoprotein in human intestinal epithelial cell monolayers. Biochem Pharmacol 48: 1528-1530, 1994.
12. Tsai SM, Lin CY, Wu SH, Hou LA, Ma H, Tsai LY and Hou MF. Side effects after docetaxel treatment in Taiwanese breast cancer patients with CYP3A4, CYP3A5, and ABCB1 gene polymorphisms. Clin Chim Acta 404: 160-165, 2009.

13. Murray S, Briasoulis E, Linardou H, Bafaloukos D and Papadimitriou C: Taxane resistance in breast cancer: Mechanisms, predictive biomarkers and circumvention strategies. Cancer Treat Rev 38: 890-903, 2012.

14. Wen K, Fu Z, Wu X, Feng J, Chen W and Qian J: Oct-4 is required for an antiapoptotic behavior of chemoresistant colorectal cancer cells enriched for cancer stem cells: Effects associated with STAT3/Survivin. Cancer Lett 333: 56-65, 2013.

15. Al-Hajj M, Wicha MS, Benito-Hernandez A, Morrison SJ and Clarke MF: Prospective identification of tumorigenic breast cancer cells. Proc Natl Acad Sci USA 100: 3983-3988, 2003.

16. Li C, Heidt DG, Dalerba P, Burant CF, Zhang L, Adsay V, Wicha M, Clarke MF and Simeone DM: Identification of pancreatic cancer stem cells. Cancer Res 67: 1030-1037, 2007.

17. Singh SK, Hawkins C, Clarke ID, Squire JA, Bayani J, Hide T, Henkelman RM, Cusimano MD and Dirks PB: Identification of human brain tumour initiating cells. Nature 432: 396-401, 2004.

18. O'Brien CA, Pollett A, Gallinger S and Dick JE: A human colon cancer cell capable of initiating tumour growth in immunodeficient mice. Nature 445: 106-110, 2007.

19. Ricci-Vitiani L, Lombardi DG, Pilozzi E, Biffoni M, Todaro M, Peschle $C$ and De Maria R: Identification and expansion of human colon-cancer-initiating cells. Nature 445: 111-115, 2007.

20. Jordan CT: Cancer stem cell biology: From leukemia to solid tumors. Curr Opin Cell Biol 16: 708-712, 2004.

21. An Y and Ongkeko WM: ABCG2: The key to chemoresistance in cancer stem cells? Expert Opin Drug Metab Toxicol 5: 1529-1542, 2009.

22. D'Arcangelo M, Todaro M, Salvini J, Benfante A, Colorito ML, D'Incecco A, Landi L, Apuzzo T, Rossi E, Sani S, et al: Cancer Stem Cells Sensitivity Assay (STELLA) in patients with advanced lung and colorectal cancer: A feasibility study. PLoS One 10: e0125037, 2015.

23. Maugeri-Saccà $\mathrm{M}$, Vigneri $\mathrm{P}$ and De Maria R: Cancer stem cells and chemosensitivity. Clin Cancer Res 17: 4942-4947, 2011.

24. Chakrabarty S: Regulation of human colon-carcinoma cell adhesion to extracellular matrix by transforming growth factor beta 1. Int J Cancer 50: 968-973, 1992.

25. Whissell G, Montagni E, Martinelli P, Hernando-Momblona X, Sevillano M, Jung P, Cortina C, Calon A, Abuli A, Castells A, et al: The transcription factor GATA6 enables self-renewal of colon adenoma stem cells by repressing BMP gene expression. Nat Cell Biol 16: 695-707, 2014.

26. Huang R, Wang G, Song Y, Tang Q, You Q, Liu Z, Chen Y, Zhang Q, Li J, Muhammand S, et al: Colorectal cancer stem cell and chemoresistant colorectal cancer cell phenotypes and increased sensitivity to Notch pathway inhibitor. Mol Med Rep 12: 2417-2424, 2015 .

27. Livak KJ and Schmittgen TD: Analysis of relative gene expression data using real-time quantitative PCR and the 2(-Delta Delta C(T)) method. Methods 25: 402-408, 2001.

28. Liang CC, Park AY and Guan JL: In vitro scratch assay: A convenient and inexpensive method for analysis of cell migration in vitro. Nat Protoc 2: 329-333, 2007.

29. Saha A, Shree Padhi S, Roy S and Banerjee B: Method of detecting new cancer stem cell-like enrichment in development front assay (DFA). J Stem Cells 9: 235-242, 2014.

30. Myint K, Li Y, Paxton J and McKeage M: Multidrug resistance-associated protein 2 (MRP2) mediated transport of oxaliplatin-derived platinum in membrane vesicles. PLoS One 10: $\mathrm{e} 0130727,2015$.

31. Buxhofer-Ausch V, Secky L, Wlcek K, Svoboda M, Kounnis V, Briasoulis E, Tzakos AG, Jaeger W and Thalhammer T: Tumorspecific expression of organic anion-transporting polypeptides: Transporters as novel targets for cancer therapy. J Drug Deliv 2013: 863539, 2013.

32. Rabik CA, Maryon EB, Kasza K, Shafer JT, Bartnik CM and Dolan ME: Role of copper transporters in resistance to platinating agents. Cancer Chemother Pharmacol 64: 133-142, 2009.

33. Furuta T, Ueda T, Aune G, Sarasin A, Kraemer KH and Pommier Y: Transcription-coupled nucleotide excision repair as a determinant of cisplatin sensitivity of human cells. Cancer Res 62: 4899-4902, 2002.

34. Garg A and Aggarwal BB: Nuclear transcription factor-kappaB as a target for cancer drug development. Leukemia 16: 1053-1068, 2002 . 
35. Yilmaz M and Christofori G: EMT, the cytoskeleton, and cancer cell invasion. Cancer Metastasis Rev 28: 15-33, 2009.

36. Pang R, Law WL, Chu AC, Poon JT, Lam CS, Chow AK, Ng L, Cheung LW, Lan XR, Lan HY, et al: A subpopulation of CD26 cancer stem cells with metastatic capacity in human colorectal cancer. Cell Stem Cell 6: 603-615, 2010.

37. Papailiou J, Bramis KJ, Gazouli M and Theodoropoulos G: Stem cells in colon cancer. A new era in cancer theory begins. Int J Colorectal Dis 26: 1-11, 2011.

38. Hermann PC, Bhaskar S, Cioffi M and Heeschen C: Cancer stem cells in solid tumors. Semin Cancer Biol 20: 77-84, 2010.

39. Wang J, Wang H, Li Z, Wu Q, Lathia JD, McLendon RE, Hjelmeland $\mathrm{AB}$ and Rich $\mathrm{JN}$ : c-Myc is required for maintenance of glioma cancer stem cells. PLoS One 3: e3769, 2008.

40. Mori R, Ishiguro H, Kuwabara Y,Kimura M, Mitsui A, Tomoda K, Mori Y, Ogawa R, Katada T, Harata K, et al: Targeting beta1 integrin restores sensitivity to docetaxel of esophageal squamous cell carcinoma. Oncol Rep 20: 1345-1351, 2008.

41. Zhang H, Ozaki I, Mizuta T, Matsuhashi S, Yoshimura T, Hisatomi A, Tadano J, Sakai T and Yamamoto K: Beta 1-integrin protects hepatoma cells from chemotherapy induced apoptosis via a mitogen-activated protein kinase dependent pathway. Cancer 95: 896-906, 2002.

42. Schenk PW, Stoop H, Bokemeyer C, Mayer F, Stoter G, Oosterhuis JW, Wiemer E, Looijenga LH and Nooter K Resistance to platinum-containing chemotherapy in testicular germ cell tumors is associated with downregulation of the protein kinase SRPK1. Neoplasia 6: 297-301, 2004.

43. Gout S, Brambilla E, Boudria A, Drissi R, Lantuejoul S, Gazzeri S and Eymin B: Abnormal expression of the pre-mRNA splicing regulators SRSF1, SRSF2, SRPK1 and SRPK2 in non small cell lung carcinoma. PLoS One 7: e46539, 2012.

44. el-Akawi Z, Abu-Hadid M, Perez R, Glavy J, Zdanowicz J, Creaven PJ and Pendyala L: Altered glutathione metabolism in oxaliplatin resistant ovarian carcinoma cells. Cancer Lett 105: $5-14,1996$.

45. Hall MD, Okabe M, Shen DW, Liang XJ and Gottesman MM: The role of cellular accumulation in determining sensitivity to platinum-based chemotherapy. Annu Rev Pharmacol Toxicol 48: 495-535, 2008.

46. Habel N, Hamidouche Z, Girault I, Patiño-García A, Lecanda F, Marie PJ and Fromigué O: Zinc chelation: A metallothionein 2A's mechanism of action involved in osteosarcoma cell death and chemotherapy resistance. Cell Death Dis 4: e874, 2013.

47. L'Espérance S, Popa I, Bachvarova M, Plante M, Patten N, Wu L, Têtu B and Bachvarov D: Gene expression profiling of paired ovarian tumors obtained prior to and following adjuvant chemotherapy: Molecular signatures of chemoresistant tumors. Int J Oncol 29: 5-24, 2006.

48. Gottesman MM and Pastan I: Biochemistry of multidrug resistance mediated by the multidrug transporter. Annu Rev Biochem 62: 385-427, 1993.

49. Levêque D and Jehl F: P-glycoprotein and pharmacokinetics. Anticancer Res 15: 331-336, 1995.

50. Roninson IB: Molecular mechanism of multidrug resistance in tumor cells. Clin Physiol Biochem 5: 140-151, 1987.

51. She JJ, Zhang PG, Wang X, Che XM and Wang ZM: Side population cells isolated from KATO III human gastric cancer cell line have cancer stem cell-like characteristics. World J Gastroenterol 18: 4610-4617, 2012.

52. Ceckova M, Vackova Z, Radilova H, Libra A, Buncek $M$ and Staud F: Effect of ABCG2 on cytotoxicity of platinum drugs: Interference of EGFP. Toxicol In Vitro 22: 1846-1852, 2008.

53. Qu H, Fang L, Duan L and Long X: Expression of ABCG2 and p-glycoprotein in residual breast cancer tissue after chemotherapy and their correlation with epithelial-mesenchymal transition. Zhonghua Bing Li Xue Za Zhi 43: 236-240, 2014 (In Chinese).

54. Hinoshita E, Uchiumi T, Taguchi K, Kinukawa N, Tsuneyoshi M, Maehara Y, Sugimachi K and Kuwano M: Increased expression of an ATP-binding cassette superfamily transporter, multidrug resistance protein 2 , in human colorectal carcinomas. Clin Cancer Res 6: 2401-2407, 2000.

55. Tamai I: Oral drug delivery utilizing intestinal OATP transporters. Adv Drug Deliv Rev 64: 508-514, 2012.
56. Plasencia C, Martínez-Balibrea E, Martinez-Cardús A, Quinn DI, Abad A and Neamati N: Expression analysis of genes involved in oxaliplatin response and development of oxaliplatin-resistant HT29 colon cancer cells. Int J Oncol 29: 225-235, 2006

57. Damia G, Guidi G and D'Incalci M: Expression of genes involved in nucleotide excision repair and sensitivity to cisplatin and melphalan in human cancer cell lines. Eur J Cancer 34: 1783-1788, 1998

58. Selvakumaran M, Pisarcik DA, Bao R, Yeung AT and Hamilton TC: Enhanced cisplatin cytotoxicity by disturbing the nucleotide excision repair pathway in ovarian cancer cell lines. Cancer Res 63: 1311-1316, 2003.

59. Rosell R, Taron M, Barnadas A, Scagliotti G, Sarries C and Roig B: Nucleotide excision repair pathways involved in Cisplatin resistance in non-small-cell lung cancer. Cancer Control 10: 297-305, 2003

60. David CJ and Manley JL: Alternative pre-mRNA splicing regulation in cancer: Pathways and programs unhinged. Genes Dev 24: 2343-2364, 2010.

61. Kim SM, Lee SY, Yuk DY, Moon DC, Choi SS, Kim Y, Han SB, Oh KW and Hong JT: Inhibition of NF-kappaB by ginsenoside $\mathrm{Rg} 3$ enhances the susceptibility of colon cancer cells to docetaxel. Arch Pharm Res 32: 755-765, 2009.

62. Wang CY, Cusack JC Jr, Liu R and Baldwin AS Jr: Control of inducible chemoresistance: Enhanced anti-tumor therapy through increased apoptosis by inhibition of NF-kappaB. Nat Med 5: 412-417, 1999.

63. Shen W, Pang H, Liu J, Zhou J, Zhang F, Liu L, Ma N, Zhang N, Zhang $\mathrm{H}$ and Liu L: Epithelial-mesenchymal transition contributes to docetaxel resistance in human non-small cell lung cancer. Oncol Res 22: 47-55, 2014.

64. Mahyar-Roemer M and Roemer K: p21 Waf1/Cip1 can protect human colon carcinoma cells against p53-dependent and p53-independent apoptosis induced by natural chemopreventive and therapeutic agents. Oncogene 20: 3387-3398, 2001.

65. Yang AD, Fan F, Camp ER, van Buren G, Liu W, Somcio R, Gray MJ, Cheng H, Hoff PM and Ellis LM: Chronic oxaliplatin resistance induces epithelial-to-mesenchymal transition in colorectal cancer cell lines. Clin Cancer Res 12: 4147-4153, 2006.

66. Bates RC, DeLeo MJ III and Mercurio AM: The epithelialmesenchymal transition of colon carcinoma involves expression of IL-8 and CXCR-1-mediated chemotaxis. Exp Cell Res 299: 315-324, 2004

67. Na DC, Lee JE, Yoo JE, Oh BK, Choi GH and Park YN: Invasion and EMT-associated genes are up-regulated in B viral hepatocellular carcinoma with high expression of CD133-human and cell culture study. Exp Mol Pathol 90: 66-73, 2011.

68. Dalerba P, Dylla SJ, Park IK, Liu R, Wang X, Cho RW, Hoey T, Gurney A, Huang EH, Simeone DM, et al: Phenotypic characterization of human colorectal cancer stem cells. Proc Natl Acad Sci USA 104: 10158-10163, 2007.

69. Leinung M, Ernst B, Döring C, Wagenblast J, Tahtali A, Diensthuber M, Stöver T and Geissler C: Expression of ALDH1A1 and CD44 in primary head and neck squamous cell carcinoma and their value for carcinogenesis, tumor progression and cancer stem cell identification. Oncol Lett 10: 2289-2294, 2015.

70. Sullivan JP, Spinola M, Dodge M, Raso MG, Behrens C, Gao B, Schuster K, Shao C, Larsen JE, Sullivan LA, et al: Aldehyde dehydrogenase activity selects for lung adenocarcinoma stem cells dependent on notch signaling. Cancer Res 70: 9937-9948, 2010.

71. Maetzel D, Denzel S, Mack B, Canis M, Went P, Benk M, Kieu C, Papior P, Baeuerle PA, Munz M, et al: Nuclear signalling by tumour-associated antigen EpCAM. Nat Cell Biol 11: 162-171, 2009.

72. Amini S, Fathi F, Mobalegi J, Sofimajidpour H and Ghadimi T: The expressions of stem cell markers: Oct4, Nanog, Sox 2, nucleostemin, Bmi, Zfx, Tcl1, Tbx3, Dppa4, and Esrrb in bladder, colon, and prostate cancer, and certain cancer cell lines. Anat Cell Biol 47: 1-11, 2014

73. Wiktorska M, Sacewicz-Hofman I, Stasikowska-Kanicka O, Danilewicz M and Niewiarowska J: Distinct inhibitory efficiency of siRNAs and DNAzymes to $\beta 1$ integrin subunit in blocking tumor growth. Acta Biochim Pol 60: 77-82, 2013. 